\title{
Torque Teno Virus and Hepatitis C Virus Co-Infection in Iranian Pediatric Thalassemia Patients
}

\author{
İranlı Pediatrik Talasemi Hastalarında Torque Teno Virüsü ve \\ Hepatit C Virüsü Koenfeksiyonu
}

\author{
Samin Alavi ${ }^{1}$, Ali Kord Valeshabad ${ }^{2}$, Zohreh Sharifi ${ }^{3}$, Kazem Nourbakhsh ${ }^{1}$, \\ Mohammad Taghi Arzanian ${ }^{1}$, Masoumeh Navidinia ${ }^{4}$, Siamak Mehdizadeh Seraj ${ }^{2}$ \\ ${ }^{1}$ Mofid Children's Hospital, , Pediatric Hematology-Oncology Department, and Pediatric Infectious Research Center, Shahid Beheshti \\ University of Medical Sciences, Tehran, Iran \\ ${ }^{2}$ Students' Scientific Research Center (SSRC), Tehran University of Medical Sciences, Tehran, Iran \\ ${ }^{3}$ Iranian Blood and Transfusion Organization, Tehran, Iran \\ ${ }^{4}$ Pediatric Infectious Research Center, Shahid Beheshti University of Medical Sciences, Tehran, Iran
}

\begin{abstract}
Objective: Torque teno virus (TTV) infects patients at risk for parenteral exposure and chronic blood transfusion, such as those with $\beta$-thalassemic. This study aimed to assess the prevalence of TTV infection and co-infection of TTV and hepatitis $\mathrm{C}$ virus (HCV) in pediatric thalassemia patients receiving chronic blood transfusion.

Material and Methods: The study included 90 pediatric thalassemia patients receiving chronic blood transfusion that presented to the Mofid Children's Hospital, Tehran, Iran. The control group included 90 healthy volunteer children. Serum TTV DNA detection via semi-nested PCR and HCV Ab were performed in all the participants. Demographic characteristics and clinical data were collected from each participant for statistical analysis.
\end{abstract}

Results: In all, $64.4 \%$ of the patients had TTV infection, versus $24.4 \%$ of the controls $(P<0.01)$. The thalassemia patients had a greater probability of having TTV and HCV infections than the controls, with a common OR of 5.60 (95\% CI: 2.94-10.69) and 2.15 (95\% CI: 1.83-2.50), respectively. In total, $17.2 \%(10 / 58)$ of the patients that were TTV positive were also $\mathrm{HCV}$ positive, whereas $6.3 \%(2 / 32)$ of the TTV-negative patients were anti-HCV antibody (Ab) positive $(P=0.14)$.

Conclusion: The prevalence of TTV and HCV infection was higher in the Iranian thalassemia patients on chronic transfusion therapy than in the controls. The high prevalence of TTV in pediatric thalassemia patients on chromic transfusion therapy may indicate the superiority of the parenteral route compared to other routs of TTV transmission.

Key Words: Thalassemia, Torque teno virus, Hepatitis C virus

Özet

Amaç: Torque teno virüsü (TTV) beta talasemik hastalar gibi kronik kan transfüzyonu ve parenteral yoldan maruz kalma açısından risk altındaki hastaları enfekte eder. Bu çalışma kronik kan transfüzyonu alan pediatrik talasemi hastalarında TTV enfeksiyonu ve TTV ile hepatit C virüsü (HCV) koenfeksiyonunun prevalansını değerlendirmeyi hedeflemiştir.

Address for Correspondence: Ali KORD VALESHABAD, M.D.,

Medical Dormitory of Tums, North Kargar Avenue 143995 Tehran, Iran

Phone: +982184743732 E-mail: ali_kord2006@yahoo.com

Received/Geliş tarihi : May 26, 2011

Accepted/Kabul tarihi : September 27, 2011 
Gereç ve Yöntemler: Çalışmaya İran'da Tahran'da Mofid Çocuk Hastanesine gelen ve kronik kan transfüzyonu alan 90 pediatrik talasemi hastası dahil edilmiştir. Kontrol grubu 90 sağlıklı gönüllü çocuğu içermiștir. Tüm katılımcılarda semi-nested PCR ve HCV Ab yoluyla serum TTV DNA'sı saptaması yapılmıştır. Her katılımcıdan istatistiksel analiz için demografik özellikler ve klinik veriler toplanmıştır.

Bulgular: Genel olarak hastaların \%64,4'ünde ve kontrol grubunun \%24,4'ünde TTV enfeksiyonu bulunmuştur (P < 0,01). Talasemi hastalarında kontrol grubuna göre TTV ve HCV enfeksiyonu bulunması olasılığı olması daha yüksek olmuştur ve ortak risk oranı sırasıyla 5,60 (\%95 GA: 2,94-10,69) ve 2,15 (\%95 GA: 1,83-2,50) bulunmuştur. Toplam olarak TTV pozitif hastalarm \%17,2'si (10/58) HCV pozitifken TTV negatif hastalarm \%6,3'ü (2/32) anti HCV antikoru (Ab) pozitiftir $(\mathbf{P}=\mathbf{0 , 1 4})$.

Sonuç: TTV ve HCV enfeksiyonu prevalansı kronik transfüzyon tedavisi alan İranlı talasemi hastalarında kontrollerden daha yüksek bulunmuştur. Kronik transfüzyon tedavisi alan pediatrik talasemi hastalarında yüksek TTV prevalansı parenteral yolun diğer TTV bulaşması yollarına göre daha sık kullanılmasına işaret edebilir.

Anahtar Sözcükler: Talasemi, Torque teno virüsü, Hepatit $C$ virüsü

\section{Introduction}

Patients with $\beta$-thalassemia major are prone to transfusion-related hepatitis because of chronic dependency on blood transfusion, and associated transfusion-related iron overload and transmission of viruses. Although the implementation of screening for hepatitis B and C virus (HBV and $\mathrm{HCV}$ ) nuclear acid and antibodies has substantially reduced the incidence of transfusion-related hepatitis, a considrable proportion of thalassemia patients still have elevated liver enzymes of unknown origin [1,2]. In 1997 a novel DNA virus - transfusion-transmitted virus (TTV) was cloned by a Japanese team from 3 patients with posttransfusion non-A-G hepatitis [3]. This non-enveloped single-stranded DNA virus was renamed Torque teno virus, a species of the genus Anelloviridae in an unassigned family that is most closely related to Circoviridae $[4,5]$. TTV infects patients at risk for parenteral exposure, such as those with thalassemia, hemophilia, and liver disease [6-9], but it can be found in other body fluids and secretions, including saliva, semen, stool, breast milk, and tears [10]. Recently, its routes of vertical and sexual transmission have been reported [11].

Primary epidemiological studies from the United Kingdom and Japan reported that TTV DNA was detectable in $25 \%-45 \%$ of patients with chronic or fulminant hepatitis of unknown origin, in 27\%-68\% of hemophiliacs, and in $1.9 \%-12 \%$ of healthy blood donors $[6,7,12]$. The prevalence of TTV among thalassemia patients was reported to vary from $50 \%$ to $100 \%$ in different studies and appears to be dependent upon diagnostic techniques, study sample size, and geographic distribution [13]. Even its prevalence among the general population has been reported to range from 1\% in the North America to as high as 54\% in Turkey
$[14,15]$. Despite the high prevalence of this virus among thalassemia patients, its potential role in cryptogenic or post-transfusion hepatitis is unclear, as most TTV-positive patients remain asymptomatic and those that progress to chronic liver disease are invariably co-infected with other hepatitis viruses [8]. There are a limited number of studies in Iran about the prevalence of TTV and its clinical importance in thalassemia patients. It remains unknown if TTV infection in thalassemia patients increases the incidence of co-infection with other hepatitis viruses such as hepatitis $C$ As such, the present study aimed to determine the prevalence of TTV infection and co-infection of TTV and $\mathrm{HCV}$ in pediatric thalassemia patients on chronic transfusion therapy in Iran.

\section{Materials and Methods}

This case-control study included all pediatric thalassemia patients on chronic transfusion therapy treated at the Mofid Children's Hospital, Tehran, Iran, and a control group of healthy volunteer children. The patients included had presented to the orthopedic outpatient clinic due to minor injuries and without a history of prior transfusion, hepatitis, surgery, parenteral treatment, or systemic diseases. All the patients were systematically examined by pediatrics residents. Informed consent was obtained from the patients or their parents if aged $<18$ years. Primary screening tests, including human immunodeficiency virus (HIV), human T-cell leukemia, and hepatitis B and C were performed in all the study participants and those with any positive result were excluded. TTV DNA and anti-HCV antibody (anti-HCV Ab) testing were performed in all the participants to determine their prevalence rates.

Anti-HCV status was determined using 2nd- and 3rdgeneration assays (Ortho Diagnostic Systems, Raritan, 
NJ). Hepatitis B surface antigen (HBsAg) status was determined via enzyme immunoassay (EIA) (Murex, Dartford, UK; and Abbott Laboratories, Chicago, IL). HCV RNA was measured via reverse transcriptase polymerase chain reaction (RT-PCR), as previously described [16]. Demographic characteristics and clinical data, including age, gender, transfusion duration, and anti-HCV Ab and TTV DNA test results were collected from each participant for statistical analysis. The study protocol was approved by the Shahid Beheshti University of Medical Sciences Ethics Committee.

\section{Isolation and determination of TTV DNA via PCR}

Semi-nested PCR was used to detect serum TTV DNA. Specifically, serum DNA purified from an equivalent of $7 \mu \mathrm{L}$ of serum was amplified according to the following PCR protocol in a 9600 thermal cycler (Perkin-Elmer, Emeryville, CA): 1 cycle at $95^{\circ} \mathrm{C}$ for 9 min; 35 cycles at 94 ${ }^{\circ} \mathrm{C}$ for $30 \mathrm{~s}, 58^{\circ} \mathrm{C}$ for $30 \mathrm{~s}$, and $72{ }^{\circ} \mathrm{C}$ for $45 \mathrm{~s} ; 1$ cycle at 72 ${ }^{\circ} \mathrm{C}$ for $7 \mathrm{~min}$. The reaction conditions were as follows: 30 pmol of each primer (sense NG059 5'-ACA GAC AGA GGA GAA GGC AAC ATG-3', antisense NG063 5'-CTG GCA TTT TAC CAT TTC CAA AGT-3') and $2.5 \mathrm{U}$ of AmpliTaq Gold DNA polymerase (Perkin-Elmer, Norwalk, CT) in a 50- $\mu \mathrm{L}$ reaction volume. Under the same conditions the second round of PCR was performed using a semi-nested primer set (sense NG061 5' GGC AAC ATG TTA TGGATA GAC TGG 3', antisense NG063) for $5 \mu \mathrm{L}$ of the amplification product. In each PCR assay 2 positive and negative controls were included. Then, the PCR products were analyzed via $2 \%$ agarose gel electrophoresis with ethidium bromide staining. Separate assays were performed for all positive samples of TTV DNA and the sequences of the PCR products were confirmed via automated sequencing on an ABI 373 sequencer (Perkin-Elmer, Foster City, CA). NG hemi-nested PCR, using primers NG059, NG061, and NG063 [6], has been used in many studies, but has been shown to have suboptimal sensitivity [17-19].

\section{Statistical analysis}

Results are reported as mean \pm standard deviation (SD) for quantitative variables and percentages for categorical variables. The 2 groups were compared using Student's t-test for continuous variables and the chi-square test (or Fisher's exact test if required) for categorical variables. Statistical significance was based on two sided tests evaluated at the $\mathrm{P}=0.05$ level of significance. All statistical analyses were performed using SPSS v.13.0 (SPSS Inc, Chicago, IL, USA) for Windows.

\section{Results}

In total, 121 pediatric thalassemia patients and 134 healthy controls were evaluated, and 31 of the thalassemia patients and 44 of the controls were excluded based on the study's exclusion criteria. TTV and HCV prevalence rates were determined in 90 thalassemia patients ( 46 boys and 44 girls) with the mean age of $14.1 \pm 5.8$ years and 90 healthy controls ( 44 boys and 46 girls) with the mean age of $13.3 \pm 6.4$ years. The patient and control groups did not significantly differ in mean age $(\mathrm{P}=0.61)$ or gender $(\mathrm{P}=$ $0.48)$. In all, $64.4 \%$ of the patients were TTV seropositive, versus $24.4 \%$ of the controls $(\mathrm{P}<0.001)$. The thalassemia patients had a greater probability of TTV and HCV seropositivity than the controls, with a common OR of 5.60 (95\% CI: 2.94-10.69, P = 0.001) and 2.15 (95\% CI: 1.83$2.50, \mathrm{P}=0.001)$, respectively.

In the patient group a significant difference was not observed in mean age, transfusion duration, or TTV and HCV seropositivity between the boys and girls $(\mathrm{P}>0.05)$. In the control group mean age was statistically higher in the girls than in the boys $(14.3 \pm 6.8$ years versus $11.4 \pm$ 4.7 years $(P=0.04)$, whereas TTV and HCV seropositivity did not differ between genders $(P>0.05)$. Table 1 shows the demographic and some clinical data for the 2 groups.

In all, 58 of the patients ( 31 boys and 27 girls) were TTV positive and 32 ( 15 boys and 17 girls) were TTV negative. Age, gender, and transfusion duration did not differ significantly between the TTV-positive and TTV-negative thalassemia patients $(P>0.05)$. In all, 17.2\% (10/58) of the TTV-positive patients had simultaneous HCV seropositivity, whereas $6.3 \%(2 / 32)$ of the TTV-negative patients were positive for anti-HCV Ab; the difference was not statistically significant $(P=0.14)$ (Table 2$)$. Among the TTV-positive thalassemia patients, there was not a significant difference in mean age, transfusion duration, or anti-HCV Ab status between the boys and girls ( $\mathrm{P}>0.05)$. Similarly, among the TTV-negative thalassemia patients, mean age, transfusion duration, and anti-HCV Ab status did not differ significantly between the boys and girls ( $\mathrm{P}>$ 0.05) (Table 2). Table 2 shows the demographic and some clinical data for the TTV-positive and TTV-negative thalassemia patients.

\section{Discussion}

The potential role and pathogenesis of TTV infection in post-transfusion hepatitis has yet to be established [20,21]. Although TTV was initially considered a new transfusiontransmitted virus in patients with acute and chronic nonA-G hepatitis, subsequent studies raised doubts about the 
Table 1: Demographic and clinical data for the 90 pediatric thalassemia patients and 90 healthy controls.

\begin{tabular}{|c|c|c|c|c|c|c|c|c|c|}
\hline \multirow[b]{2}{*}{ Variables } & \multicolumn{4}{|c|}{ Patients } & \multicolumn{4}{|c|}{ Controls } & \multirow[t]{2}{*}{$\mathbf{P}$} \\
\hline & $\begin{array}{c}\text { Boys } \\
(n=46)\end{array}$ & $\begin{array}{c}\text { Girls } \\
(\mathrm{n}=44)\end{array}$ & $\mathbf{P}$ & $\begin{array}{c}\text { Total } \\
(\mathbf{n}=90)\end{array}$ & $\begin{array}{c}\text { Boys } \\
(\mathbf{n}=30)\end{array}$ & $\begin{array}{c}\text { Girls } \\
(\mathrm{n}=60)\end{array}$ & $P$ & $\begin{array}{c}\text { Total } \\
(\mathbf{n}=90)\end{array}$ & \\
\hline Age (years) & $14.2 \pm 5.5$ & $14.0 \pm 6.2$ & 0.87 & $14.1 \pm 5.8$ & $11.4 \pm 4.7$ & $14.3 \pm 6.8$ & 0.04 & $13.3 \pm 6.4$ & 0.61 \\
\hline $\begin{array}{l}\text { Transfusion } \\
\text { duration } \\
\text { (months) }\end{array}$ & $18.3 \pm 15.9$ & $22.6 \pm 21.2$ & 0.28 & $20.3 \pm 18.8$ & - & - & & - & \\
\hline $\begin{array}{l}\text { TTV positive } \\
(\%)\end{array}$ & $31(67.4)$ & $27(61.4)$ & 0.55 & $58(64.4)$ & $6(20.0)$ & $15(25.0)$ & 0.60 & $21(24.4)$ & 0.001 \\
\hline $\begin{array}{l}\text { HCV positive } \\
(\%)\end{array}$ & $8(17.4)$ & $4(9.1)$ & 0.25 & $12(13.3)$ & $0(0.0)$ & $0(0.0)$ & - & $0(0.0)$ & 0.001 \\
\hline
\end{tabular}

Table 2: Demographic and clinical data for the TTV-positive and TTV-negative thalassemia patients.

\begin{tabular}{|c|c|c|c|c|c|c|c|c|c|}
\hline \multirow{2}{*}{ Variables } & \multicolumn{4}{|c|}{ TTV (+) } & \multicolumn{4}{|c|}{ TTV (-) } & \multirow[t]{2}{*}{$\mathbf{P}$} \\
\hline & $\begin{array}{c}\text { Boys } \\
(n=31)\end{array}$ & $\begin{array}{c}\text { Girls } \\
(n=27)\end{array}$ & $\mathbf{P}$ & $\begin{array}{c}\text { Total } \\
(n=58)\end{array}$ & $\begin{array}{c}\text { Boys } \\
(n=15)\end{array}$ & $\begin{array}{c}\text { Girls } \\
(\mathrm{n}=17)\end{array}$ & $\mathbf{P}$ & $\begin{array}{c}\text { Total } \\
(n=32)\end{array}$ & \\
\hline Age (years) & $14.6 \pm 5.9$ & $14.9 \pm 6.3$ & 0.85 & $14.7 \pm 6.02$ & $13.5 \pm 4.7$ & $12.6 \pm 6.0$ & 0.64 & $13.0 \pm 5.3$ & 0.18 \\
\hline $\begin{array}{l}\text { Transfusion } \\
\text { duration } \\
\text { (months) }\end{array}$ & $15.8 \pm 13.5$ & $25.1 \pm 18.9$ & 0.12 & $20.39 \pm 13.7$ & $23.6 \pm 20.9$ & $17.3 \pm 15.1$ & 0.33 & $20.26 \pm 18.7$ & 0.97 \\
\hline $\begin{array}{l}\text { Anti-HCV Ab } \\
(\%)\end{array}$ & $8(25.8)$ & $2(7.4)$ & 0.06 & $10(17.2)$ & $0(0.0)$ & $2(11.8)$ & 0.17 & $2(6.3)$ & 0.14 \\
\hline
\end{tabular}

hypothesis that TTV infection leads to clinical manifestation in all infected patients [15]. In the present study pediatric thalassemia patients had a greater probability of TTV and HCV seropositivity than the controls, with a common OR of 5.60 (95\% CI: 2.94-10.69, P = 0.001) and 2.15 (95\% CI: 1.83-2.50, P = 0.001), respectively. As previously reported [22,23], this finding may indicate the superiority of the parenteral route compared to other routes of TTV transmission. In all, 64.4\% of the present study's pediatric thalassemia patients had TTV, whereas only $24.4 \%$ of controls, which did not have a history of blood transfusion, hepatitis, parenteral treatment, or any known diseases, were TTV positive. The infected controls might have been infected via non-parenteral routes, such as saliva, semen, stool, breast milk, or tears [10].

Zandieh et al. reported that $57.2 \%$ of Iranian thalassemia patients and $20 \%$ of healthy controls were TTV positive [24]. The reported prevalence of TTV infection var- ies by study due to differences in diagnostic techniques, study sample size, and geographic distribution [13]; even sequencing of TTV clones from thalassemia patients showed that 1 patient had multiple TTV variants [13]. Ozyürek et al. reported that $63 \%$ of Turkish thalassemia patients had the virus [15]; additionally, $73 \%$ and $69 \%$ of Italian pediatric and adult thalassemia patients, respectively, had the virus $[25,26]$, and $73.4 \%$ of thalassemia patients in Taiwan had the virus [23]. Such variation in the prevalence of TTV infection has been noted in the general population of different countries. Epidemiological studies reported that the prevalence of TTV infection is $1 \%$ in North America [20], 10\% in Europe [27], 10\%-62\% in South America [10], 22\% in Italy, 34\% in Japan [14], and $54 \%$ in Turkey [15].

Age, gender, and transfusion duration did not differ significantly between the present study's TTV-positive and TTV-negative thalassemia patients $(P>0.05)$. In contrast, 
previous evaluation of TTV infection in 250 thalassemia patients in Ahwaz (a province in southern Iran) showed that there was a significant correlation between TTV infection, and age and history of blood transfusion [24]. The present study included pediatric thalassemia patients in Tehran and that other study included patients from southern Iran (Ahwaz); however, in addition to the difference in geographic location of the 2 study populations, they were ethnically different. It has been reported that the distribution of TTV infection varies with geographic region and country, which might account for the differences between the 2 studies' findings $[10,14,15,20,23,27]$.

The present study has some limitations. The presented data and results were based on TTV DNA amplification via PCR using only 1 set of primer. It is possible that other variants of TTV DNA existed in our samples that were not detectable using this set. Samples found to be positive via NG hemi-nested PCR may subsequently undergo restriction fragment length polymorphism analysis for genotype identification, but this was not applied in the present study. The clinical impacts of this virus on liver function enzymes and histopathologic changes were not assessed in all the patients and were not used in the analyses. Thus, we plan to design studies in the future to assess the clinical importance and features of TTV in thalassemia patients.

\section{Conclusion}

The prevalence of TTV and HCV was higher in the pediatric thalassemia patients on chronic transfusion therapy than in the healthy controls. The high prevalence of TTV in this group of patients may indicate the superiority of the parenteral route compared to other routes of TTV transmission.

\section{Conflict of Interest Statement}

The authors of this paper have no conflicts of interest, including specific financial interests, relationships, and/ or affiliations relevant to the subject matter or materials included.

\section{References}

1. Okamoto H, Mayumi M: TT virus: virological and genomic characteristics and disease association. J Gastrenterol 2001; 36: $519-529$

2. Chen BP, Rumi MG, Colombo M, Lin YH, Ramaswamy L, Luna J, Liu JK, Prati D, Mannucci PM: TT virus is present in a high frequency of Italian hemophilic patients transfused with plasma derived clotting factor concentrates. Blood 1999; 94: 4333-4336
3. Nishizawa T, Okamoto H, Konishi K, Yoshizawa H, Miyakawa Y, Mayumi M: A novel DNA virus (TTV) associated with elevated transaminase levels in posttransfusion hepatitis of unknown etiology. Biochem Biophys Res Commun 1997; 241: 92-97

4. Hino S: TTV, a new human virus with single stranded circular DNA genome. Rev Med Virol 2002; 12: 151-158

5. Takahashi K, Ohta Y, Mishiro S: Partial 2.4-kb sequence of TT virus (TTV) genome from eight japans isolates: Diagnostic and phylogenetic implications. Hepatol Res 1998; 12: 111-120

6. Okamoto H, Nishizawa T, Kato N, Ukita M, Ikeda H, Iizuka H, Miyakawa Y, Mayumi M: Molecular cloning and characterization of a novel DNA virus (TTV) associated with posttransfusion hepatitis of unknown origin. Hepatol Res 1998; 10: 1-16

7. Simmonds P, Davidson F, Lycett C, Prescott LE, MacDonald DM, Ellender J, Yap PL, Ludlam CA, Haydon GH, Gillon J, Jarvis LM: Detection of a novel DNAvirus (TTV) in blood donors and blood products. Lancet 1998; 352: 191

8. Poovorawan Y, Tangkijvanich P, Theamboonlers A, Hirsch P: Transfusion transmissible virus TTV and its putative role in the etiology of liver disease. Hepatogastroenterology 2001; 48 (37): 256-260

9. Cossart Y: TTV-A virus searching for a disease. J Clin Virol 2000; 17: 1-3

10. Matsubara H, Michitaka K, Horiike N, Yano M, Akbar SM, Torisu M, Onji M: Existence of TT virus DNA in extracellular body fluids from normal healthy Japanese subjects. Intervirology 2000; 43 (1): 16-19

11. Schröter M, Polywka S, Zöllner B, Schäfer P, Laufs R, Feucht HH: Detection of TT virus DNA and GB virus type C/Hepatitis G virus RNA in serum and breast milk: Determination of mother-to-child transmission. J Clin Microbiol 2000; 38 (2): 745-747

12. Naoumov NV, Petrova EP, Thomas MG, Williams R: Presence of a newly described human DNA virus (TTV) in patients with liver disease. Lancet 1998; 352: 195-197

13. Kondili LA, Pisani G, Beneduce F, Morace G, Gentili G, Ballati G, Rapicetta M: Prevalence of TT virus in healthy children and thalassemic pediatric and young adult patients. J Pediatr Gastroenterol Nutr 2001; 33 (5): 629-632

14. Masia G, Ingianni A, Demelia L, Faa G, Manconi PE, Pilleri G, Ciancio A, Rizzetto M, Coppola RC: TT virus infection in Italy prevalence and genolypes in healty, subjects, viral diseases and asymptomatic infection by parenterally transmitted viruses. J Viral Hepatitis 2001; 8: 384-390 
15. Ozyürek E, Ergünay K, Kuskonmaz B, Unal S, Cetin M, Ustaçelebi S, Gürgey A, Gümrük F: Transfusion-transmitted virus prevalence in Turkish patients with thalassemia. Pediatr Hematol Oncol 2006; 23 (4): 347-353

16. Chen HL, Chang MH, Ni YH, Hsu HY, Kao JH, Chen PJ: Hepatitis $G$ virus infection in normal and prospectively followed posttransfusion children. Pediatr Res 1997; 42: 784-787

17. Kato T, Mizokami M, Orito E, Nakano T, Tanaka Y, Ueda R, Hirashima N, Iijima Y, Kato T, Sugauchi F, Mukaide M, Shimamatsu K, Kage M, Kojiro M.: High prevalence of TT virus infection in Japanese patients with liver diseases and inblood donors. J Hepatal 1999; 31: 221-227

18. Takahashi K, Hoshino H, Ohta Y, Yoshida N, Mishiro S: Very high prevalence of TT virus (TTV) infection in general population of Japan revealed by a new set of PCR primers. Hepato Res 1998; 12: 233-239

19. Toyoda H, Naruse M, Yokozaki S, Morita K, Nakano I, Itakura A, Okamura M, Fukuda Y, Hayakawa T: Prevalence of infection with TT virus (TTV), a novel DNA virus, in healthy Japanese subjects, newborn infants, cord blood and breast milk. J Infect 1999; 38: 198-199

20. Blejer JL, Salamone HJ: Is TT virus (TTV) a true hepatitis virus cause? Medicina (B Aires) 2000; 60: 631-638

21. Dhenain M, Boulétreau A, Bourguignon F, Poujol I, Chemin I, Fabry J, Vanhems P: The TT virus: Review of the literature. Clin Invest Med 2000; 23 (6): 355-365
22. Hu YW, Al-Moslih MI, Al Ali MT, Uzicanin S, Perkins H, Yi QL, Rahimi Khameneh S, Wu J, Brown EG: Clinical outcome of frequent exposure to Torque Teno virus (TTV) through blood transfusion in thalassemia patients with or without hepatitis C virus (HCV) infection. J Med Virol 2008; 80 (2): 365-371

23. Hsu HY, Ni YH, Chen HL, Kao JH, Chang MH: TT virus infection in healthy children, children after blood transfusion and children with non-A to E hepatitis or other liver diseases in Taiwan. J Med Virol 2003; 69 (1): 66-71

24. Zandieh T, Babaahmadi B, Pourfathollah A, Galedari H, Emam J, Jalalifar MA: Transfusion Transmitted virus (TTV) infection in Thalassemic patients. Iranian J Publ Health 2005; 34: 24-28

25. Sampietro M, Tavazzi D, Martinez F, et al: TT virus infection in adult B-thalassemia major patients. Hematologia 2001; 86 (1): 39-43

26. Toyoda H, Fukuda Y, Nakano I, Katano Y, Yokozaki S, Hayashi K, Ito Y, Suzuki K, Nakano H, Saito H, Takamatsu J: TT virus genotype changes frequently in multiply transfused patients with hemophilia but rarely in patients with chronic hepatitis $C$ and in healthy subjects. Transfusion 2001; 41: 1130-1135

27. Takács M, Balog K, Tóth G, Balogh Z, Szomor KN, Brojnás J, Rusvai E, Minárovits J, Berencsi G: TT virus in Hungary: Sequence heterogeneity and mixed infections. Immunol Med Microbiol 2003; 35: 153 -157 